Climate change and macrolepidopteran biodiversity in Finland

\author{
Virtanen, $\mathrm{T}$.
}

Elsevier

1999

Virtanen, T. and Neuvonen, S. 2002. Climate change and macrolepidopteran biodiversity in Finland. Chemosphere: Global Change Science 1(4):439-448

http://hdl.handle.net/1975/280

Downloaded from Helda, University of Helsinki institutional repository.

This is an electronic reprint of the original article.

This reprint may differ from the original in pagination and typographic detail.

Please cite the original version. 


\title{
Climate change and macrolepidopteran biodiversity in Finland
}

\author{
Tarmo Virtanen *, Seppo Neuvonen \\ University of Turku, Section of Ecology, Department of Biology and Kevo Subarctic Research Institute, FIN-20014 Turku, Finland
}

Accepted 30 July 1998

\begin{abstract}
The northern limit of macrolepidopteran distributions in Finland is usually determined by climatic factors. Food plants probably determine distributions in less than $3 \%$ of species. The species richness decreases by 65 species for each degree of latitude northward, i.e. 93 species $(12.0 \%$ of total) per degree celsius in mean summer temperature. As lepidopteran species are usually good dispersers, any climate warming will promote increases in species richness as southern species shift their ranges northwards. Conversely, the distribution of northern species, comprising $11 \%$ of Finnish species, may shrink due to habitat loss from warming climate. Species overwintering as eggs or adults would be expected to benefit from a rise in winter temperatures. Species overwintering as pupae are most likely to increase the number of generations per year. (c) 1999 Elsevier Science Ltd. All rights reserved.
\end{abstract}

Keywords: Climate warming; Butterflies; Moths; Life history characters; Geographical gradients

\section{Introduction}

Most insects are good dispersers and have a long history in a fluctuating climate (Solbreck, 1993; Ashworth, 1996). Considerable shifts northward of butterfly and moth ranges occurred in Finland in the thirties and forties, when mean temperatures were higher than in the preceding decades, corresponding to normal temperatures in Central Europe during 1901-1930 (Kaisila, 1962; Heino et al., 1996).

An increase in greenhouse gases can lead to an additional warming of the atmosphere and the earth's surface, and the surface warming at high

\footnotetext{
${ }^{*}$ Corresponding author. E-mail: tarmo.virtanen@metla.fi
}

latitudes may be greater than the global average (Schneider, 1993; Houghton et al., 1996). Higher overwinter survival, higher growth rates and a longer breeding season may lead to increased densities of insect populations, and some species are expected to extend their ranges to higher latitudes and elevations as the climate warms (Peters, 1992; Solbreck, 1993; Williams and Liebhold, 1995). A major hypothesis explaining patterns in species richness, the species-energy hypothesis (Wright, 1983), states that energy-related climatic variables are essential predictors of the variation in total species richness. However, insects with a predominantly northern distribution (e.g. sawflies; Kouki et al., 1994) may suffer in a warming climate.

It might be possible to predict future responses of lepidopterans to climate change by analysing 
and interpreting current distributions according to large-scale geographic variations in climate. The ability to predict future shifts in distributions depends on several critical assumptions: (1) the distribution limits of macrolepidoptera are only rarely set by the distribution of the host plant; (2) the observed patterns reflect climatic variation, not underlying patterns in host plant species richness; (3) the possible confounding effects of host plant type (annual, perennial, woody) on the relationships between other life history characteristics can be solved. As an example, species overwintering as larvae constitute the largest part of macrolepidoptera in northern Finland while the incidence of overwintering in other stages (egg, pupa or adult) increases towards the south (Mikkola, 1980), see also (Hayes, 1982). There are at least two potential explanations for this pattern: (1) the relative overwintering success of different stages varies over the latitudinal gradient (Mikkola, 1980), (2) the overwintering stage is related to the host plant type of the insect species (Hayes, 1982; Niemelä et al., 1982) and the relative abundance of different host plant types changes over the latitudinal gradient, thus creating the observed pattern.

In this study, we examined species richness of butterflies and moths in Finland and describe how their life histories are related to different vegetation zones today. We realize that there are uncertainties about how climate may change in Fennoscandia (Lehman and Keigwin, 1992; Räisänen, 1994). However, we will discuss how a possible climate warming might change the species composition and life history characteristics of insect fauna related to a latitudinal shift of vegetation zones. We also try to characterize the species that are most likely to suffer if temperatures increase in northern Europe.

\section{Material and methods}

From the literature (Appendix A), we gleaned information on over 900 species of Macrolepidoptera (butterflies 114, moths over 790) found in Finland and determined that 780 species have persistent populations. We classified species according to the following characteristics of their biology and life history: distribution, diapause stage, food plant type and number of yearly generations (Table 1). We assumed that phylogenetic constraints do not confound our conclusions, because the characters we classified are relatively independent of taxonomy (e.g., vary within genera; Hayes, 1982; Miller, 1992; Miller, 1996; Quinn et al., 1997). Vegetation zones follow (Heikkinen et al., 1995) (cf. Ahti et al., 1968). Mean summer (May-September) temperatures in 1961-1990 were obtained from meteorological stations in hemiboreal (10 stations), southern boreal (20), middle boreal (16), northern boreal (10) and orohemiarctic/northern boreal (3) zone (Ilmatieteen laitos, 1995).

Because other life history characters are related to food plant type (Hayes, 1982; Hunter, 1995), we also analysed characters using only species $(N=228)$ that feed on Betula, Populus or Salix. These three plant genera are abundant and distributed throughout Finland, so the potential confounding effect of food plant type on distribution patterns of insects is eliminated.

\section{Results and discussion}

\subsection{The number of macrolepidopteran species is mainly explained by the climate}

The number of butterfly and moth species in northernmost Finland is only one fifth of that in southwestern Finland (Fig. 1; Table 1). This means that, on average, 65 species are lost for each degree of latitude northward. This gradient is steeper than that of established vascular plants in Finland, when gradients are measured as percentages of total diversity (Lahti et al., 1988). About 5\% (42 of 780) of Finnish butterfly and moth species are mono- or stenophagous on foodplants whose distribution is limited to the southern or middle parts of Finland, and only about half of these species can be found regularly over the whole distribution area of their food plants. This is in agreement with the conclusion of Quinn et al. (1997), that the range of a host plant almost never constrains the distribution of British macrolepidopteran species. Furthermore, the number of butterfly and moth 
Table 1

Species classification

A. Distribution type

We formed nine groups from the southern to the northernmost species based on vegetarian zone-classifications (Fig. 1). A list of species belonging to each distribution class is available from the authors upon request.

1. Migratory species that usually do not survive winters in Finland $(N=28)$

2. Species only in the hemiboreal zone $(N=198)$

3. Species only in the hemi- and southern boreal zone $(N=212)$

4. Species only in the hemi-, southern and middle boreal zone $(N=153)$

5. Species only in the hemi-, southern, middle and northern boreal zone $(N=73)$

6. Species that live throughout Finland $(N=62)$

7. Species that can be found in the southern or middle boreal zone but are more common in northern boreal or orohemiarctic zones $(N=29)$

8. Species only in the northern boreal and orohemiarctic zone $(N=23)$

9. Species only in the orohemiarctic zone $(N=30)$

\section{B. Diapause stage}

It is usually a fixed character, butterflies and moths overwinter as an egg, larva, pupa or adult. Species that overwinter in two different stages $(N=22)$ were weighted by 0.5 .

\section{Type of larval food plant}

Annual: species feeding mainly on annual herbs

Perennial: species feeding mainly on perennial herbs or low $(<1 \mathrm{~m}$ height $)$ shrubs

Tree: species feeding mainly on trees or higher shrubs

Lichen-feeders $(N=21)$ : omitted from the analysis including the food plant type

\section{Number of the generations per year}

1 or less gen./year: species that have never been documented to have more than one generation per year in Finland

$>1$ gen./year: species that regularly or occasionally have been found to have more than one generation per year in Finland

species feeding on Betula, Salix and Populus (total $N=228$ ) decreases northwards as rapidly as the number of all macrolepidopteran species: 210, 180, $124,72,41$ species in hemiboreal, southern boreal, middle boreal, northern boreal and orohemiarctic zone, respectively. This decrease is apparent despite the fact that trees and shrubs in these three genera are abundant throughout Finland and the number of species in these genera does not decrease northwards (Myklestad and Birks, 1993). Thus, the species richness or abundance of host plants is not sufficient to explain the geographical pattern in macrolepidopteran species richness, suggesting that climate is important in limiting the ranges and species richness of insects.

The species richness of butterflies in Britain decreases by 0.4 species (or $0.69 \%$ of the total) for each $10 \mathrm{~km}$ further north (Turner et al., 1987). The respective figure we calculated for Finnish macrolepidoptera is $0.72 \%$ per $10 \mathrm{~km}$. However, the species richness of Finnish butterflies decreases only by $0.42 \%$ per $10 \mathrm{~km}$ northwards. The butterfly species richness in Britain is highly correlated with climatic variables (summer temperature and duration of sunshine account for nearly $80 \%$ of the variation); each degree increase in mean summer (May-September) temperatures means an addition of 6.6 species $(11.4 \%$ of total) of British butterflies (Turner et al., 1987). The corresponding increase in Finland is 93 macrolepidopteran species $(12.0 \%$ of total) per degree in mean summer temperature. Thus, the pattern in boreal Finland matches that of temperate Britain and both give support to the 'species-energy hypothesis' (Wright, 1983).

\subsection{Diapause stage, food plant type and distribution}

In Finland, species that overwinter as eggs are concentrated in the six southern distribution classes (Fig. 2). But in North America, butterflies 


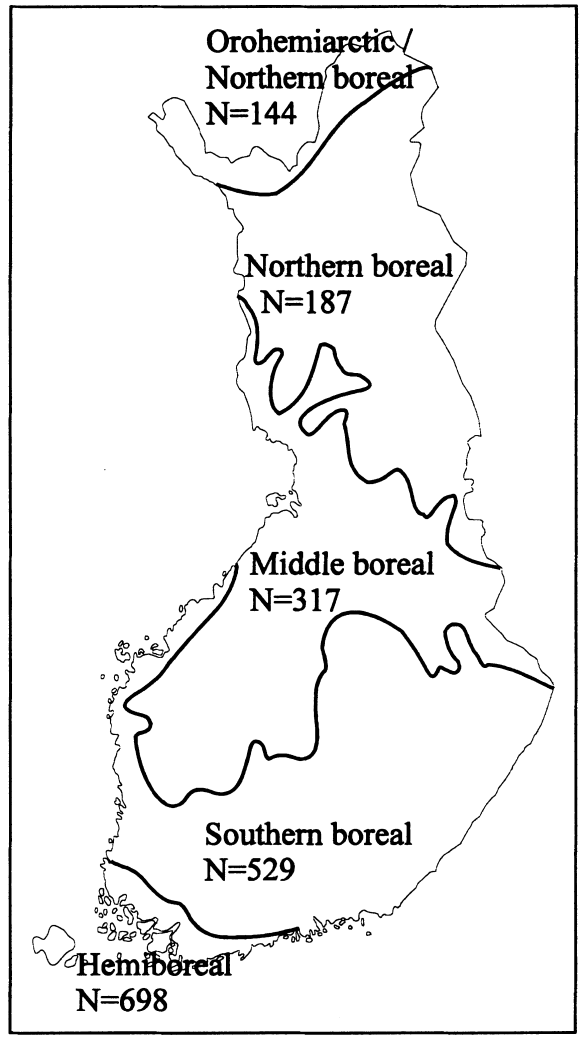

Fig. 1. Vegetation zones and the number of butterfly and moth species per zone. In the northernmost zone orohemiarctic vegetation is dominant at higher altitudes, northern boreal at lower altitudes.

that overwinter as eggs were found in cool areas (Hayes, 1982). However, most of the North American species included in the analysis were from the temperate region and species with northern distributions (corresponding to our study area) were perhaps under represented (only 180 of the 500 North American butterflies were included in (Hayes, 1982)). Detailed studies of individual species that overwinter as eggs show that extremely cold winter temperatures may limit the distribution and/or outbreaks of these species in northern Fennoscandia (Tenow and Nilssen, 1990; Virtanen et al., 1996; Virtanen et al., 1998).

Our literature review shows that larval diapause is common in every distribution class, but its proportion increase in the northernmost ones (Fig. 2). In almost all cases, the Finnish larvae overwinter under ground covered by snow, an unusual habit for species overwintering as eggs. Snow has a great moderating effect on ground temperatures. Even when air temperatures dip below $-30^{\circ} \mathrm{C}$, which is not uncommon in Finland, the ground temperature under a half meter of snow cover does not go below $-10^{\circ} \mathrm{C}$ (Seppälä, 1990). Even snow $5 \mathrm{~cm}$ deep is sufficient to prevent the death of moths overwintering in the ground (Lamb et al., 1985).

Many species in the northernmost Finland (25 in our data) overwinter two or more times as a larva, often first when newly emerged and secondly when full-grown (Hayes, 1982; Danks, 1992). Because summers are extremely variable in the arctic, larvae may need to overwinter several times before they experience favourable summer conditions (Sotavalta et al., 1980; Kukal and Kevan, 1987).

Overwintering as a pupa is a trait that occurs anywhere in Finland but is proportionately more frequent in the south (Fig. 2). There is a similar pattern for butterflies in temperate parts of North America where pupal owerwintering is widely distributed but most common for species inhabiting warmer regions (Hayes, 1982). In Finland, the most northerly species that overwinter as pupae are geometrids that overwinter under the thick snowlayer well sheltered from low temperatures.

Species overwintering as an adult are few and are restricted to southern distributions in Finland (Fig. 2). They are probably the least cold tolerant and have difficulty in surviving the harsh Finnish winters; many of them are migratory (19\% of species that overwinter as adults are migratory vs. $2 \%$ of those that overwinter in other stages; Fig. 2).

The life histories of herbivorous insects are related to characteristics of their food plants such as structure, abundance, seasonal availability and quality (Niemelä et al., 1982). Species feeding on annual herbs generally have an overwintering pupa while species feeding on perennial herbs or low shrubs have a larva as the most common overwintering stage (Fig. 3). Species that overwinter as eggs or adults are usually tree-feeding, as are also most of the species that overwinter as pupae (Fig. 3). Lepidopterans that feed on annuals are 


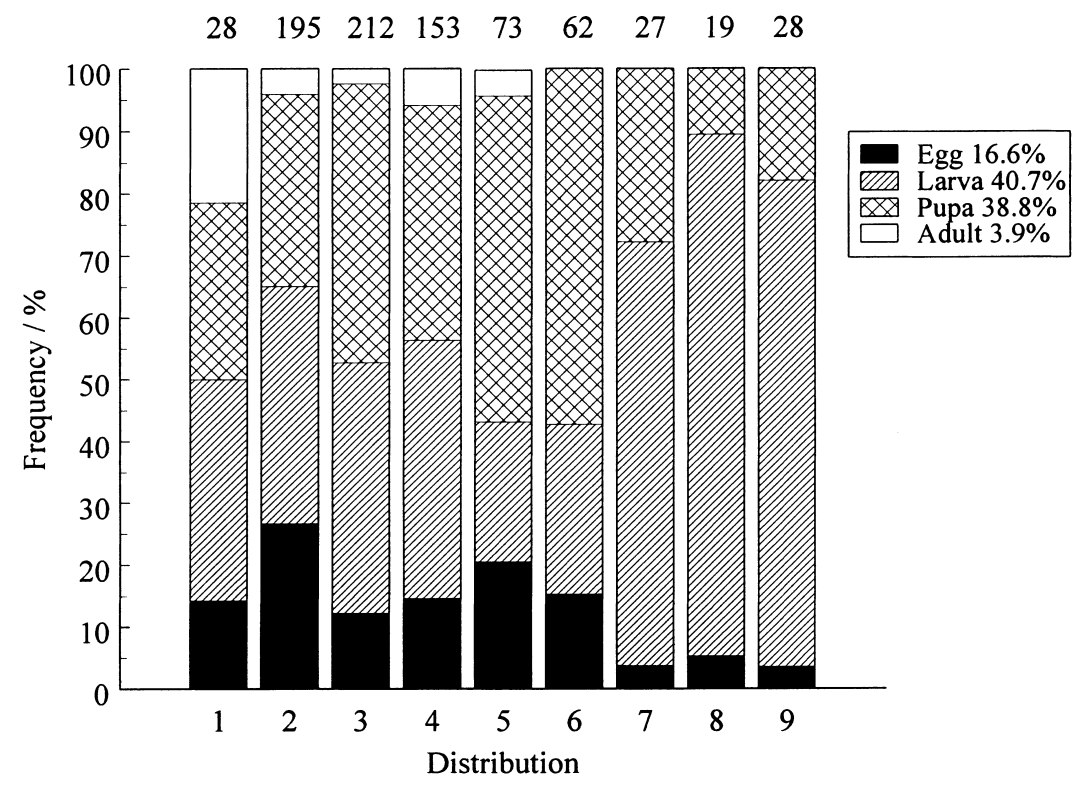

Fig. 2. Frequency of species diapause stages in different distribution types from south to north (distribution type classification in Table 1). Numbers above bars show the number of species in distribution classes and percentages in legend are overall means.

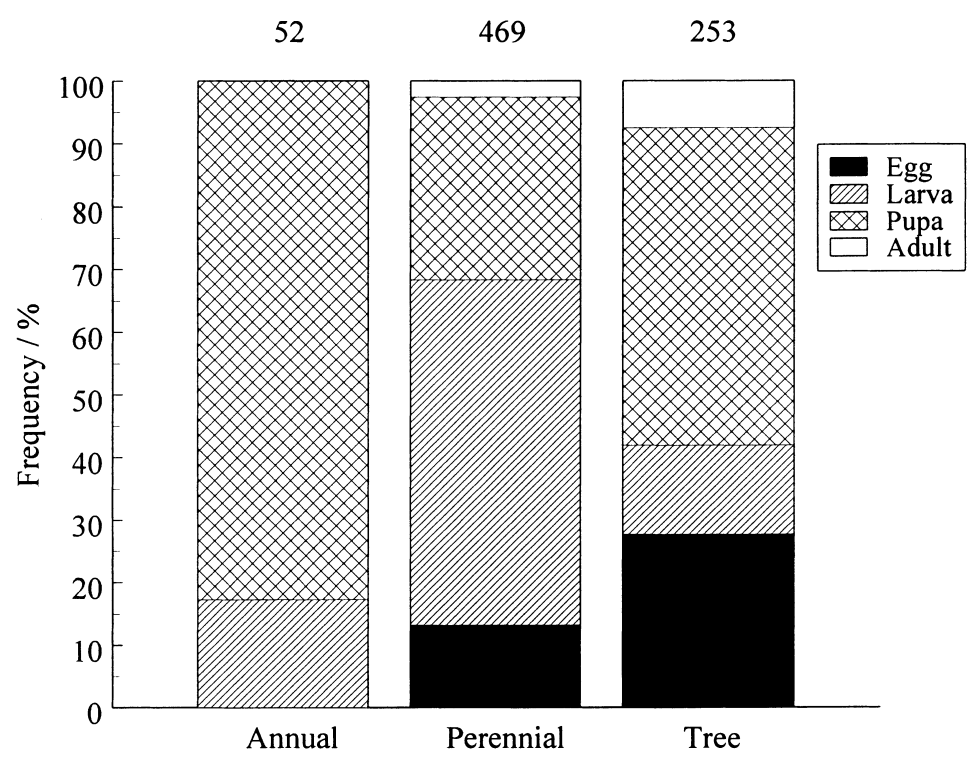

Fig. 3. Frequency of species diapause stages in relation to food plant type. Numbers above bars show the number of species in food plant type classes.

found only in the five southernmost distribution classes while those feeding on perennials are more common in the three northernmost classes. This trend is mainly the result of many species in the north that feed on low shrubs, especially Vaccinium. 
The taxa that feed only on Betula, Populus or Salix contained fewer species that overwinter as larvae than the whole data set $(24 \%$ vs. $41 \%$, Figs. 2-4). Nevertheless, the relationship between distribution class and over-wintering stage was similar for both data sets (Figs. 2 and 4). This means that the pattern of an increasing proportion of species overwintering as larvae in the north is not an artefact of differences in the species or type of food plant.

\subsection{Responses of southern species to climate warming}

Most of the macrolepidopteran species in Finland have a southern distribution; over $80 \%$ belong to distribution classes 1-5 (Table 1). The positive relationship between warm summers and abundance and/or species richness of Lepidoptera (especially butterflies) that has been well documented and discussed from temperate areas (Turner et al., 1987; Pollard, 1988; Pollard et al., 1995) is also important in Finland (Kaisila, 1962; Mikkola, 1997). Thus, under any scenario of cli- mate warming, the number of species is expected to increase as the ranges shift northwards in response to warmer temperatures.

There are about 20 regularly multivoltine species in Finland, but about 170 more species may have a second (usually less abundant) generation in southern Finland. For many of these 170 species, the second generation develops only in favourable years. Having multiple generations per year seems to be linked to pupal overwintering (Fig. 5). No egg-and only one adult-overwintering species (Aglais urticae (L.)) has been documented to have more than one generation per year (Fig. 5). Because the number of generations per year correlates with the temperature sum of the area (Scriber and Hainze, 1987), climate warming may cause a second generation to become more common in southern areas and to occur further north.

\subsection{Responses of northern species to climate warming}

From a conservation point of view, attention should be paid to those species that might suffer

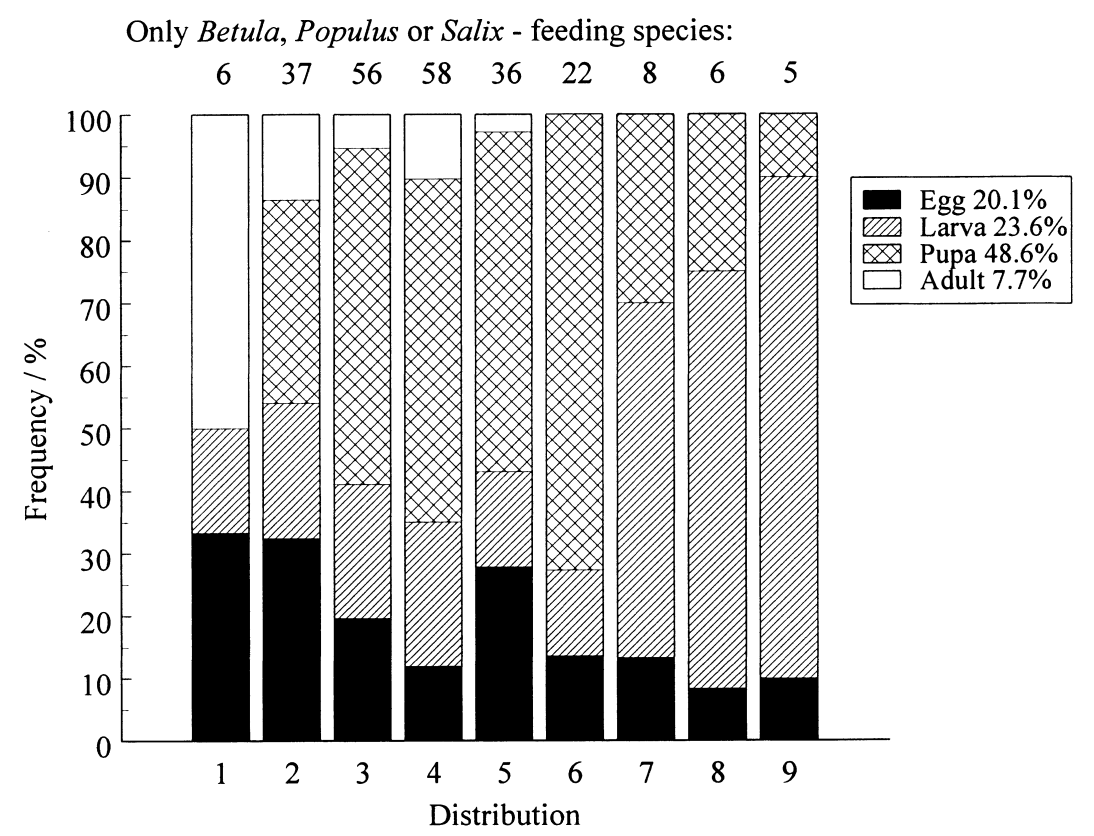

Fig. 4. Frequency of species diapause stages in different distribution types from south to north, only Betula, Salix or Populus feeding species. Numbers above bars show the number of species in distribution classes and percentages in legend are overall means. 


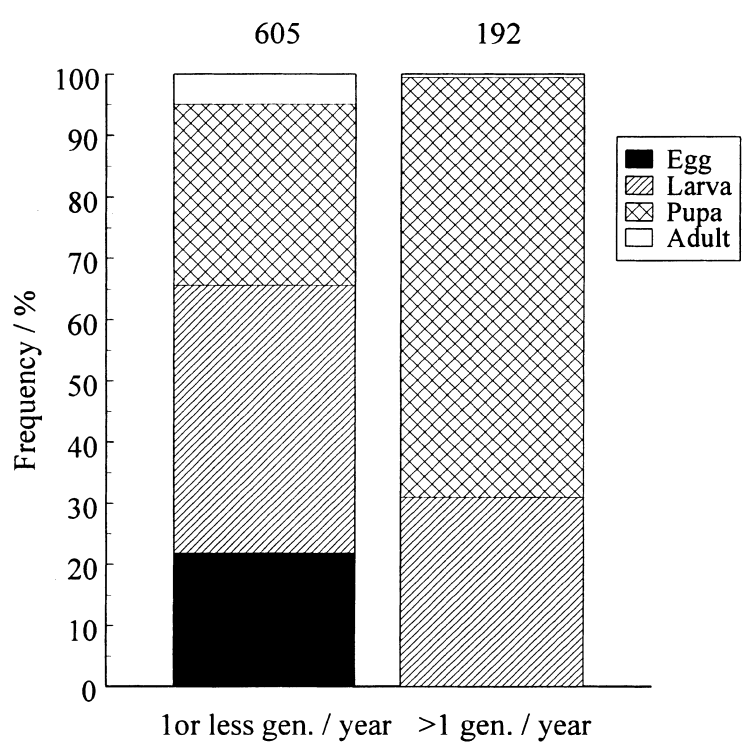

Fig. 5. Frequency of species diapause stages in relation to the number of yearly generations.

from climate warming. The distribution of 84 species (11\% of all persistent species) is centred in the north (Table 1). According to Finnish entomological literature (Appendix A) about two thirds of these are rare or very rare (also knowledge about some species is limited) and typically many of the species are habitat specialists occurring in boreal bogs or in alpine habitats. In a longer time scale, their potential habitat could decrease, as it has been predicted that global warming should lead to general decrease in the areal extent of tundra and boreal vegetation (Woodward, 1992).

In Fennoscandia, the Arctic Ocean limits the potential northward expansion of insects trying to escape warmer temperatures. Shrinking habitat may have negative affects on the following 31 Finnish species, which are mainly found in treeless tundra (nomenclature according to Varis et al., 1995): Circumpolar species; Acerbia alpina, Entephria polata, Psychophora sabini, Colias hecla, $C$. nastes, Agriades glandon, Boloria napaea, Clossiana polaris, $C$. improba, $C$. chariclea, Oeneis norna, $O$. bore, Xestia quieta, Polia richardsoni, Discestra melanopa, Sympistis lapponica, S. zetterstedtii, and Eurasian species; Entephria byssata, E. nobiliaria,
E. flavicinctata, Perizoma minoratum, Eupithecia fennoscandica, Pygmaena fusca, Glacies coracina, Pyrgus andromedae, Hypodryas iduna, Erebia pandrose, Xestia lyngei, X. lorezi, Lasionycta leucocycla, and L. staudingeri.

Not only shifts in vegetation zones caused by climate warming but, probably more importantly, also loss of habitat due to changed land-use presents a threat to several species. Some of the northern species have already decreased in Southern Finland due to draining of bogs (Marttila et al., 1990; Mikkola, 1997).

\section{Conclusions}

Both the species richness of Macrolepidoptera and the proportion of species overwintering in different stages show clear latitudinal patterns in Finland. These patterns are retained in the subset of species that feed on trees abundant throughout Finland, indicating that they are probably determined by climatic factors rather than host plant distributions.

There is variation between the predictions of different General Circulation Models concerning $\mathrm{CO}_{2}$-induced warming in Northern Europe (Räisänen, 1994) and it even may be possible that the flow of warm Atlantic surface waters into the Norwegian sea could decrease (Lehman and Keigwin, 1992). However, a generally accepted scenario is that mean temperatures will rise and the warming will be larger in winter than in summer (Schneider, 1993; Houghton et al., 1996; Räisänen, 1994). Despite uncertainties, the evidence warrants a consideration of how a possible climate warming might change the species composition and life history characteristics of insect fauna. The positive relationship between warm summers and abundance and/or species richness of Lepidoptera (Turner et al., 1987; Pollard, 1988; Pollard et al., 1995) suggests that species richness would likely increase as ranges shift northwards in response to warmer temperatures. Climate warming may also cause a second generation to become more common in southern areas and to occur further north.

The relative diversity of macrolepidopteran overwintering stages increases southwards (Figs. 2 
and 4). Insect species that overwinter as eggs or adults and are not covered by snow, are especially sensitive to direct effects of changes in minimum winter temperatures. These species probably benefit from winter warming. Winter warming may also have negative effects: if the length of the snow free period increases or snow totally melts in the middle of the winter sudden cold periods without snowcover could be more disastrous to species overwintering in the ground. The distribution of $11 \%$ of Finnish persistent macrolepidopteran fauna is centred in the north and 31 species are living mainly in treeless tundra habitats. Their potential habitat could decrease in the future if global warming leads to a general decrease in the areal extent of tundra and boreal vegetation (Woodward, 1992), especially because the Arctic Ocean limits the potential northward shift of tundra habitat in Fennoscandia.

\section{Acknowledgements}

We thank Matt Ayres, Janne Henriksson, Juhani Itämies, Lauri Kaila, Jocelyn Martel, Kai Ruohomäki, Kari Saikkonen, Jukka Salo, Toomas Tammaru, Karen Wiebe and Brian Wilsey for the comments on the manuscript. The study was financed by the Academy of Finland (SILMU, Finnish Research Programme on Climate Change) and by the foundation of Emil Aaltonen.

\section{Appendix A. Butterfly and moth data references}

Koponen, S., Laasonen, E.M., Linnaluoto, E.T., 1982. Lepidoptera of Inari Lapland, Finland, Kevo Notes 6, 1-36.

Linnaluoto, E.T., Koponen, S., 1980. Lepidoptera of Utsjoki, northernmost Finland, Kevo Notes 5, 1-68.

Marttila, O., Haahtela, T., Aarnio, H., Ojalainen, P., Suomen päiväperhoset, Kirjayhtymä, Helsinki, 1990.

Marttila, O., Saarinen, K., Haahtela, T., Pajari, M., Suomen kiitäjät ja kehrääjät, Kirjayhtymä, Porvoo, 1996.
Mikkola, K., Jalas, I., 1977. Suomen perhoset, Yökköset I, Otava, Helsinki.

Mikkola, K., Jalas, I., 1979. Suomen perhoset, Yökköset II, Otava, Helsinki.

Mikkola, K., Jalas, I., Peltonen, O., 1985. Suomen perhoset, Mittarit I, Tampereen kirjapaino Oy, Tampere.

Mikkola, K., Jalas, I., Peltonen, O., 1989. Suomen perhoset, Mittarit II, Hangon kirjapaino, Hanko.

Seppänen, E., 1969. Suurperhostemme talvehtimisasteet. Ann. Entomol. Fenn. 35, 129 152.

Seppänen, E., 1954. Suomen suurperhostoukkien ravintokasvit, Die Nahrungspflanzen der Grobschmettrlings-raupen Finnlands. Animalia Fennica 8, 1-268.

Valle, K.J., 1935. Suomen eläimet, Animalia Fennica 2. Suurperhoset, Macrolepidoptera I. Päiväperhoset, Diurna, WSOY, Porvoo.

Valle, K.J., 1937. Suomen eläimet, Animalia Fennica 3. Suurperhoset, Macrolepidoptera II. Kiitäjät, Sphinges and Kehrääjät, Bombyces, WSOY, Porvoo.

Valle, K.J., 1940. Suomen eläimet, Animalia Fennica 4. Suurperhoset, Macrolepidoptera III. Yökköset, Noctuae, WSOY, Porvoo.

Valle, K.J., 1946. Suomen eläimet, Animalia Fennica 5. Suurperhoset, Macrolepidoptera IV. Mittarit, Geometrae, WSOY, Porvoo.

\section{References}

Ahti, T., Hämet-Ahti, L., Jalas, J., 1968. Vegetation zones and their sections in northwestern Europe. Ann. Bot. Fenn. 5, 169-211.

Ashworth, A.C., 1996. The response of arctic Carabidae (Coleoptera) to climate change based on the fossil record of the quaternary period. Ann. Zool. Fennici 33, 125-131.

Danks, H.V., 1992. Long life cycles in insects. Can. Entomol. 124, 167-187.

Hayes, J.L., 1982. A study of the relationships of diapause phenomena and other life history characters in temperate butterflies. Am. Nat. 120, 160-170.

Heikkinen, O., Obrebska-Starkel, B., Tuhkanen, S., 1995. Introduction: the timberline - a changing battlefront. In: Heikkinen, O., Obrebska-Starkel, B., Tuhkanen, S. (Eds.), Environmental Aspects of the Timberline in Finland and in 
the Polish Carpathians. Uniwersytet Jagiellonski, Kraków, pp. 7-16.

Heino, R., Tuomenvirta, H., Drebs, A., 1996. Climatic changes in Northern Europe. Publications of the Academy of Finland 4/96, pp. 35-40.

Houghton, J.T., Meira Filho, L.G., Callander, B.A., Harris, N., Kattenberg, N., Maskell, K. (Eds.), 1996. Climate Change 1995. The Science of Climate Change, Cambridge University Press, Cambridge.

Hunter, A.F., 1995. Ecology, life history, and phylogeny of outbreak and nonoutbreak species. In: Capuccino, N., Price, P. (Eds.), Population Dynamics, New Approaches and Synthesis. Academic Press, San Diego, pp. 41-64.

Ilmatieteen laitos, 1995. Kuukausikatsaus Suomen ilmastoon, Climate Monthly Bulletin of the Finnish Meteorological Institute. Finnish Meteorological Institute, Helsinki, vol. 89 (5-9).

Kaisila, J., 1962. Immigration und expansion der Lepidopteren in Finnland in den Jahren 1869-1960. Acta. Entomol. Fenn. $18,1-452$.

Kouki, J., Niemelä, P., Viitasaari, M., 1994. Reversed latitudinal gradient in species richness of sawflies (Hymenoptera, Symphyta). Ann. Zool. Fennici 31, 83-88.

Kukal, O., Kevan, P.G., 1987. The influence of parasitism on the life history of a high arctic insect, Gynaephora groenlandica (Wöcke) (Lepidoptera, Lymantriidae). Can. J. Zool. 65, 156-163.

Lahti, T., Kurtto, A., Väisänen, R.A., 1988. Floristic composition and regional species richness of vascular plants in Finland. Ann. Bot. Fennici 25, 281-291.

Lamb, R.J., Turnock, W.J., Hayhoe, H.N., 1985. Winter survival and outbreaks of Bertha armyworm, Mamestara configurata (Lepidoptera, Noctuidae) on Canola. Can. Entomol. 117, 727-736.

Lehman, S.J., Keigwin, L.D., 1992. Sudden changes in North Atlantic circulation during the last deglaciation. Nature 356 , 757-762.

Marttila, O., Haahtela, T., Aarnio, H., Ojalainen, P., Suomen päiväperhoset, Kirjayhtymä, Helsinki.

Mikkola, K., 1980. Miten perhoset selviävät pakkasista. Suomen luonto $39,12-15$.

Mikkola, K., 1997. Population trends of Finnish Lepidoptera during 1961-1990. Entomologica Fennica 8, 121-143.

Miller, J.S., 1992. Host plant associations among prominent moths. Bioscience 42, 50-57.

Miller, W.E., 1996. Population behavior and adult feeding capability in Lepidoptera. Env. Entomol. 25, 213-226.

Myklestad, A, Birks, H.J.B., 1993. A numerical analysis of the distribution patterns of Salix L. species in Europe. J. Biogeogr. 20, 1-32.

Niemelä, P., Tahvanainen, J., Sorjonen, J., Hokkanen, T., Neuvonen, S., 1982. The influence of host plant growth form and phenology on the life strategies of Finnish macrolepidopterous larvae. Oikos 39, 164-170.

Peters, R.L., 1992. Conservation of biological diversity in the face of climate change. In: Peters, R.L., Lovejoy, T.E.
(Eds.), Global Warming and Biological Diversity. Yale University Press, New Haven, London, pp. 15-30.

Pollard, E., 1988. Temperature, rainfall and butterfly numbers. J. Appl. Ecol. 25, 819-828.

Pollard, E., Moss, D., Yates, T.J., 1995. Population trends of common British butterflies at monitored sites. J. Appl. Ecol. 32, 9-16.

Quinn, R.M., Gaston, K.J., Roy, R.B., 1997. Coincidence between consumer and host occurrence: Macrolepidoptera in Britain. Ecol. Entomol. 22, 197-208.

Räisänen, J., 1994. A comparison of the results of seven GCM experiments in Northern Europe. Geophysica 30, 3-30.

Schneider, S.H., 1993. Scenarios of global warming. In: Kareiva, P., Kingsolver, J.G., Huey, R.B. (Eds.), Biotic Interactions and Global Change. Sinuar, Sunderland, Massachusetts, pp. 9-23.

Scriber, J.M., Hainze, J.H., 1987. Geographic invasion and abundance as facilitated by differential host plant utilization abilities.In: Barbosa, P., Schulz, J. (Eds.), Insect Outbreaks. Academic Press, New York, pp. 433-468.

Seppälä, M., 1990. Depth of snow and frost on a palsa mire, Finnish Lapland. Geogr. Ann. A 72 (2), 191-201.

Solbreck, C., 1993. Predicting insect faunal dynamics in a changing climate - a north European perspective. In: Holten, J.J., Paulsen, G., Oechel, W.C. (Eds.), Impacts of Climatic Change on Natural Ecosystems, with Emphasis on Boreal and Arctic/alpine areas. Norwegian Institute for Nature Research, Trondheim, pp. $176-185$.

Sotavalta, O., Karvonen, E., Korpela, S., Korpela, J., 1980. The early stages and biology of Acerbia alpina (Lepidoptera, Arctiidae). Notulae Entomologicae 60, 89-95.

Tenow, O., Nilssen, A., 1990. Egg cold hardiness and topoclimatic limitations to outbreaks of Epirrita autumnata in northern Fennoscandia. J. Appl. Ecol. 27, 723-734.

Turner, J.R.G., Gatehouse, C.M., Corey, C.A., 1987. Does solar energy control organic diversity? Butterflies, moths and the British climate. Oikos 48, 195-205.

Varis, V., Ahola, M., Albrecht, A., Jalava, J., Kaila, L., Kerppola, S., Kullberg, J., 1995. Checklist of Finnish Lepidoptera - Suomen perhosten luettelo. Sahlbergia 2, 180.

Virtanen, T., Neuvonen, S., Nikula, A., Varama, M., Niemelä, P., 1996. Climate change and the risks of Neodiprion sertifer outbreaks on Scots pine. Silva Fennica 30, 169-177.

Virtanen, T., Neuvonen, S., Nikula, A., 1998. Modelling topoclimatic patterns of egg mortality of Epirrita autumnata (Lep:, Geometridae) with Geographical Information System: predictions for current climate and warmer climate scenarios. J. Appl. Ecol. 35, in press.

Williams, D.W., Liebhold, A.M., 1995. Forest defoliators and climate change: potential changes in spatial distribution of outbreaks of Western spruce budworm (Lepidoptera: Torticidae) and Gypsy moth (Lepidoptera: Lymantriidae). Env. Entomol. 24, 1-9.

Woodward, F.I., 1992. A review of the effects of climate on vegetation: Ranges, competition, and composition. In: 
Peters, R.L., Lovejoy, T.E. (Eds.), Global Warming and Biological Diversity. Yale University Press, New Haven, London, pp. 105-123.
Wright, D.H., 1983. Species-energy theory: an extension of species-area theory. Oikos 41, 495-506. 